\title{
Analisis Adaptasi Pendidikan Berbasis Teknologi dalam Menghadapi Pandemi Covid-19
}

\author{
Lusiani \\ Akademi Maritim Nusantara Cilacap, Cilacap \\ anilusi0287@gmail.com
}

Diterima 31 Juli 2021, direvisi 28 Agustus 2021, diterbitkan 06 Oktober 2021

\begin{abstract}
Abstrak
Adanya pandemi memberikan dampak terhadap bidang pendidikan yakni kegiatan belajar mengajar dilaksanakan pendidik serta peserta didik, sehingga kedua belah pihak harus mampu beradaptasi dengan pembelajaran berbasis teknologi, selain itu pihak sekolah serta lingkungan belajar memberikan andil dalam proses adaptasi. Tujuan kajian ini yakni menganalisis adaptasi pendidikan berbasis teknologi dalam menghadapi pandemi covid-19. Kajian berikut menggunakan metode berupa descriptive content analysis study. Analisis dilaksanakan melalui berbagai artikel ilmiah terkait adaptasi pendidikan berbasis teknologi dalam menghadapi pandemi Covid-19. Artikel ilmiah didapatkan dari jurnal nasional serta beragam referensi sejenis lainnya. Hasil kajian menunjukkan adaptasi pendidikan berbasis teknologi dalam menghadapi pandemi Covid19 dalam berbagai bentuk antara lain a) kesiapan SDM: Pendidik memberikan materi melalui media online google classroom, google meet, zoom, google form, youtube, peserta didik menerima materi menggunakan media sejenis yang diberikan Pendidik. b). Kesiapan materi pembelajaran: materi dikemas secara menarik, mudah dipahami dalam berbagai bentuk seperti power point, video pembelajaran/praktikum. c). Kesiapan model pembelajaran relevan yakni model pembelajaran berbasis student centered, pembelajaran berpusat pada siswa dengan materi yang dikemas Guru berbentuk video, siswa mengembangkannya menggunakan berbagai sumber, kemudian mengkaitkannya antara permasalahan dan teori. d). Kesiapan fasilitas pembelajaran berbasis IT: pendidik, peserta didik, pihak sekolah, lingkungan belajar memerlukan perangkat pembelajaran berbasis online dengan jaringan internet stabil, leptop, hand phone, kuota internet. Kendala utama pada proses adaptasi pendidikan berbasis teknologi yakni kesiapan sarana dan prasarana berupa terbatasnya perangkat leptop, hand phone, kuota internet. Hal ini membutuhkan kerjasama berbagai pihak yang terlibat dalam dunia pendidikan sebagai adaptasi pendidikan berbasis teknologi dalam menghadapi Pandemi Covid-19.
\end{abstract}

Kata kunci: adaptasi, pendidikan, teknologi, covid-19

\begin{abstract}
The existence of a pandemic has an impact on the education sector, namely teaching and learning activities are carried out by educators and students, so that both parties must be able to adapt to technology-based learning, besides that the school and the learning environment contribute to the adaptation process. The purpose of this study is to analyze the adaptation of technology-based education in the face of the COVID-19 pandemic. The following study uses a method in the form of descriptive content analysis study. The analysis was carried out through various scientific articles related to the adaptation of technology-based education in the face of the Covid-19 pandemic. Scientific articles are obtained from national journals and various other similar references. The results of the study show the adaptation of technology-based education in dealing with the Covid-19 pandemic in various forms, including a) HR readiness: Educators provide material through online media such as Google Classroom, Google Meet, Zoom, Google Form, YouTube, students receive material using similar media used given by educators. $b$ ). Readiness of learning materials: the material is packaged in an attractive, easy-to-understand way in various forms such as power points, learning videos/practicums. c). The readiness of the relevant learning model is a student-centered learning model, student-centered learning with material packaged by the teacher in the form of videos, students develop it using various sources, then linking it between problems and theory. d). Readiness of IT-based learning facilities: educators, students, schools, learning environments require online-based learning tools with stable internet networks, laptops, mobile phones, internet quotas. The main obstacle in the adaptation process of
\end{abstract}


technology-based education is the readiness of facilities and infrastructure in the form of limited laptop devices, mobile phones, internet quotas. This requires the cooperation of various parties involved in the world of education as an adaptation of technology-based education in the face of the Covid-19 Pandemic.

Keywords: adaptation, education, technology, covid-19

\section{Pendahuluan}

Pandemi Covid-19 yang dialami seluruh warga Indonesia mendorong Pemerintah menentukan kebijakan penerapan kegiatan belajar mengajar online di rumah sebagai pengganti kegiatan belajar mengajar konvensional yakni tatap muka. Kebijakan kegiatan belajar mengajar online tersebut memberikan dampak terhadap efektifitas kegiatan belajar mengajar jika belum dibersamai dengan kesiapan sekolah, pendidik, serta siswa saat pelaksanaan kegiatan belajar mengajar melalui online. [1]

Secara menyeluruh negara mendapat dampak dari pandemi, hingga beberapa negara yang menentukan status lockdown serta mengantisipasi sebagai cara menghentikan rantai menyebarnya virus, sehingga mengakibatkan berbagai bidang mengalami kendala salah satunya yakni pendidikan dengan menerapkan pada sekolah-sekolah agar diliburkan, yang bermaksud pencegahan menyebarnya virus Covid-19.[2]

Adanya pandemi berdampak pada proses belajar mengajar yang dilaksanakan pendidik serta peserta didik, kedua belah pihak harus mampu beradaptasi dengan pembelajaran literasi teknologi. Kegiatan pembelajaran yang dilakukan memiliki tujuan yang harus dicapai agar kualitas pembelajaran lebih baik hingga mampu mempengaruhi kualitas pendidikan secara umum. Proses pembelajaran dapat dikategorikan berhasil atau tidak. Hal itu dapat ditentukan dengan penilaian atau evaluasi hasil belajar. Pengukuran hasil belajar harus mencakup keseluruhan segi penilaian yakni kognitif, afektif, serta psikomotorik. Ketiga domain tersebut menjadi komponen yang saling terkait dengan komponen penilaian pembelajaran. Penilaian dalam ranah kognitif meliputi penilaian yang dilakukan di sekitar otak manusia (siswa), penilaian ranah afektif seputar sikap siswa, sedangkan penilaian ranah psikomotor seputar keterampilan siswa saat pembelajaran berlangsung. Pendidik baik guru maupun dosen harus memiliki desain kegiatan pembelajaran yang dapat mencakup ketiga domain tersebut, selain itu pendidik harus mampu menerapkan kolaborasi ketiga domain tersebut dalam setiap materi yang disajikan, sehingga tujuan akhir pembelajaran dapat terwujud. sesuai dengan kegiatan pembelajaran yang telah dilakukan. Kegiatan belajar mengajar pada umumnya memiliki tujuan pembelajaran yang akan diperoleh pada akhir pelajaran yang disebut penilaian hasil belajar. Tujuan pembelajaran dapat terwujud apabila mendapat dukungan penuh dari berbagai faktor, antara lain pendidik, siswa, sumber belajar, bahan ajar, dan lingkungan belajar. Faktor-faktor tersebut harus berkelanjutan untuk keberhasilan kegiatan belajar mengajar.

Tolak ukur keberhasilan suatu pembelajaran tergantung pada pencapaian tujuan kompetensi belajar peserta didik yang mencakup kognitif, afektif, psikomotorik dan terwujudnya nilai positif yang diterapkan saat berpikir serta dalam tindakan. Semua siswa dipastikan mempunyai penguasaan kompetensi terhadap sebuah bahan ajar dan dilanjutkan dengan materi selanjutnya adalah tujuan dari ketuntasan pembelajaran. Ketuntasan pembelajaran mengacu pada kompetensi yang diperoleh dan didukung oleh indikator dalam pengukuran level pencapaiannya. Keseluruhan segi ketuntasan pembelajaran bisa diperoleh melalui kerjasama antara dua pihak yakni pendidik dan peserta didik. [3]

Hal tersebut membuat penulis tertarik menganalisis adaptasi pendidikan berbasis teknologi dalam menghadapi pandemi covid-19.

\section{Materi dan Metode}

Permasalahan yang muncul antara lain masih adanya pendidik yang mempunyai kompetensi yang kurang baik dalam lingkup memanfaatkan teknologi saat kegiatan belajar mengajar, kurangnya fokus siswa sehingga diperlukan pengawasan orang tua selama kegiatan pembelajaran, tuntutan jaringan yang selalu tersedia dan kuota internet untuk pembelajaran, baik siswa maupun guru.[4] 
WFH merupakan bentuk himbauan pemerintah dalam memerangi penyebaran Covid. penegakannya di hampir setiap lembaga, termasuk lembaga pendidikan. WFH dapat diartikan sebagai tahapan pembelajaran yang sebelumnya dilaksanakan di dalam kelas (langsung) dan saat ini terhenti sementara serta dialihkan melalui kegiatan pembelajaran dengan cara online. Siswa serta pendidik tetap melaksanakan kegiatan belajar mengajar seperti umumnya, namun dilaksanakan pada masingmasing tempat yang berbeda. Setelah beberapa minggu melaksanakan kegiatan pembelajaran dengan sistem online, segala permasalahan serta kendala mulai muncul. Diantaranya, tidak menyeluruh siswa memiliki fasilitas yang sama misalnya handphone; sebagian besar siswa hanya mempunyai ponsel biasa. Terbatasnya kuota serta jaringan yang tidak baik pun merupakan kendala. Kegiatan belajar mengajar jarak jauh di masa wabah ini, mendapatkan berbagai kendala dalam pelaksanaannya lapangan meskitelah terdapat edaran Pemerintah supaya pembeajaran di rumah melalui online. Beberapa peserta didik tidak bisa mengikuti kegiatan belajar mengajar online dikarenakan tidak ada sinyal jaringan internet. Hampir menyeluruh wali siswa dengan golongan ekonomi menengah ke bawah juga tidak memiliki smartphone sebagai sarana pembelajaran online bagi anak-anaknya. Beberapa pendidik juga dipaksa melakukan inovasi yakni mengadaptasi materi kegiatan belajar mengajar yang dibagikan melalui TV Pemerintah, kemudian mendistribusikannya pada siswa. Kegiatan pembelajaran saat di rumah memerlukan pengawasan langsung orang tua. Kendala kegiatan belajar mengajar jarak jauh memerlukan terobosan dikarenakan sebagian besar daerah yang memiliki teknologi yang terbatas, jaringan lemah, serta terbatasnya kuota internet. Kurikulum serta bahan ajar dipandang memerlukan perumusan yang sesuai dengan tujuan tercapainya kualitas pendidikan. Masih banyak kendala lainnya yang timbul selama menggunakan teknis online. Bahan yang disajikan belum seluruhnya dimengerti peserta didik; mereka bingung ketika mendapatkan materi yang disampaikan oleh siswa.[5]

Minimnya akses teknologi serta internet yang cepat serta handal dirasakan oleh pelajar di daerah-daerah maupun dari keluarga kurang mampu. Minimnya akses teknologi maupun konektivitas internet yang baik menjadi hambatan agar selalu belajar, khususnya untuk peserta didik dari keluarga kurang mampu. Pelaksanaan program pembelajaran jarak jauh untuk siswa yang tidak mempunyai akses internet menyulitkan mereka untuk mengikuti pembelajaran jarak jauh.[3]

Saat mulai pelaksanaannya sebagian besar peserta didik yang merespon dengan baik kelas online, namun setelah dilakukan proses perkuliahan online sebagian besar peserta didik yang mendapat kesulitan kegiatan belajar mengajar. Situasi ini menyebabkan turunnya kualitas belajar mengajar bagi peserta didik dan kualitas pengajaran oleh pendidik. Beberapa masalah timbul karena adanya gangguan yang kurang kondusif. Pikiran terpecah serta sulitnya fokus. Pendapat salah satu pihak yang sudah menjalankan kelas online sejak Maret karena pandemi. Dijelaskan yakni pihak tersebut lebih suka kegiatan pembelajaran di kampus, dikarenakan menjadi lebih terfokus. Lanjutnya menjelaskan, karena belajar online tidak hanya tugas yang semakin menumpuk, tetapi juga banyak gangguan saat belajar. Kelas tatap muka memiliki nuansa yang berbeda, interaksi langsung cenderung mendukung proses pembelajaran. [5]

Pelaksanaan pembelajaran online oleh pendidik memiliki kelebihan dan kekurangan. Pelaksanaan pembelajaran online dilakukan oleh pendidik dengan menggunakan smartphone, laptop dan jaringan internet dalam kegiatan belajar mengajar agar proses penyampaian materi pelajaran kepada siswa tetap berjalan. Kelebihan pembelajaran online adalah lebih efektif dan efisien; siswa lebih leluasa mempelajari materi secara mandiri; memperluas jangkauan pembelajaran; belajar mandiri. Kekurangan dari pembelajaran online adalah sulit dilaksanakan jika infrastruktur tidak mendukung; akses internet tidak merata di setiap tempat; fasilitas untuk siswa tidak sama. Manfaat pembelajaran online yang paling dirasakan oleh pendidik adalah peningkatan kompetensi dalam penggunaan teknologi pembelajaran. Adaptasi pendidik terhadap pembelajaran online di masa pandemi adalah mengumpulkan informasi untuk meningkatkan pemahaman mengenai pembelajaran online melalui media internet seperti Google dan YouTube, untuk berdiskusi dengan teman sebaya. Proses adaptasi tersebut tidak lepas dari kendala yang disebabkan oleh kurangnya waktu bagi pendidik saat mempelajari makna pembelajaran online, namun kendala 
tersebut dapat diatasi dengan baik dengan bantuan berbagai pihak dan motivasi pendidik untuk terus belajar cara memaknai pembelajaran online.[6]

Belajar online serta bekerja dari rumah bagi guru adalah perubahan yang wajib dilaksanakan agar dapat terus mengajar siswa. Pendidikan jarak jauh mempunyai tujuan untuk meningkatkan kualitas pendidikan serta relevansinya, yaitu menambah akses serta perluasan pendidikan yang merata. Pembelajaran online memiliki berbagai dampak bagi siswa, yaitu siswa masih merasa bingung; pasif, tidak terlalu kreatif serta produktif; akumulasi informasi yang kurang berguna; mengalami stres; serta meningkatkan kompetensi literasi bahasa. Hal tersebut bisa digunakan sebagai evaluasi supaya kegiatan belajar mengajar online mampu diusahakan bisa diterima secara baik oleh siswa dengan tidak mengurangi esensi dari pendidikan secara utuh.[7]

Pemerintah telah mengeluarkan kebijakan penerapan new normal di beberapa sektor termasuk sektor pendidikan. Kondisi ini membuat masyarakat harus beradaptasi dengan situasi new normal dengan mematuhi aturan yang dibuat oleh pemerintah. Adaptasi ini dimaknai sebagai cara pandang dan perilaku baru sehingga pada akhirnya akan menjadi budaya baru. Perkembangan dunia pendidikan semakin pesat, hal tersebut ditinjau dengan makin beragam metode kegiatan belajar mengajar yang dimanfaatkan, dan penggunaan berbagai media yang bermanfaat bagi peningkatan kualitas hasil belajar. Perkembangan berbagai metode dan media pembelajaran sejalan dengan pesatnya kemajuan teknologi. Bentuk pengembangan yang dapat dimanfaatkan adalah dengan menggunakan elearning. Adopsi e-learning berdampak pada peningkatan penggunaan media sosial. Aspek terpenting adalah penyesuaian belajar ketika baru ke normal. E-learning merupakan pembelajaran berbasis teknologi internet untuk memudahkan seseorang dalam menerima ilmu pengetahuan dan meningkatkan keterampilan siswa dan siswi. New normal merupakan kebijakan untuk membuka kembali kegiatankegiatan masyarakat yang sebelumnya terbatas dengan menerapkan protokol kesehatan. Metode e-learning diharapkan tidak mengganggu sistem pembelajaran dengan tetap menjalankan kebiasaan pembiasaan sebelum pandemi dengan melakukan penyesuaian dengan keadaan saat ini.[8]

Pandemi mewajibkan keseluruhan segi pendidikan melakukan adaptasi serta menyelesaikan semester secara utuh. Kebijakan social dan physical distancing dalam rangka meminimalisir penyebaran virus memacu setiap segi pendidikan agar menjadikan kelas aktif meski sekolah diliburkan. Menutup sekolah merupakan strategi mitigasi paling efektif dalam meminimalisisasi menyebarnya wabah ke pserta didik. Penyelesaian permasalahan yakni diterapkannya kegiatan belajar mengajar dari rumah yang menggunakan beragam fasilitas pendukung. Kegiatan belajar mengajar online dijadikan langkah penyelesaian permasalahan efektif dalam membuat kelas aktif meskipun pembelajaran tidak dilakukan di sekolah. Cara kegiatan belajar mengajar tersebut penting dilakukan evaluasi berdasarkan kondisi setempat karena persebaran fasilitas dan kemampuan orang tua dalam menyediakan fasilitas kegiatan belajar mengajar online memiliki perbedaaan dengan siswa. Pembelajaran online memudahkan perpindahan informasi dalam beragam situasi serta kondisi. Manfaat mudahnya belajar online didukung oleh beragam platform dimulai dengan diskusi hingga tatap muka virtual. Kuncinya yakni mengoptimalkan kompetensi peserta didik untuk belajar di masa pandemi.[9]

Metode dalam kajian ini berupa descriptive content analysis study yakni analisis isi dengan mendeskripsikan isi berdasarkan informasi maupun suatu teks terkait. [10]. Beragam artikel ilmiah dianalisis dalam kaitannya dengan pembelajaran berbasis teknologi infomasi pada pendidikan tinggi kemaritiman saat pandemi. Sumber artikel berasal dari jurnal nasional maupun beragam sumber lain yang relevan.

\section{Hasil dan Pembahasan}

\section{Langkah-Langkah Persiapan/Adaptasi Pembelajaran di Masa Pandemi}

Adaptasi sekolah saat menerapkan pembelajaran jarak jauh di masa pandemi yaitu merubah manajemen pendidikan menggunakan sistem pembelajaran jarak jauh, mengoptimalkan peran kepala sekolah, kepala kurikulum serta pendidik, berinteraksi dengan terus menerus bersama wali siswa serta menggunakan aplikasi WhatsApp dengan optimal yang dijadikan media komunikasi saat kegaiatan belajar mengajar.[4] 
Pembelajaran jarak jauh harus dilaksanakan sebagai proses adaptasi kebijakan pemerintah terkait pandemi. Aplikasi TIM untuk pembelajaran jarak jauh merupakan salah satu yang dipandang baik. Beberapa pihak menyatakan sangat senang dapat bertemu serta mengamati deskripsi para pendidik dalam hal materi yang diberikan dalam pertemuan tersebut. Memberikan kemudahkan adaptasi peserta didik dengan TIM walaupun pendidik mereka baru menggunakannya untuk pertama kalinya serta banyak dari mereka belum paham teknologi. Walaupun mahasiswa diharuskan memiliki tambahan teknis dan peralatan agar dapat beradaptasi dengan aplikasi TIM seperti komputer atau perangkat smart phone serta kuota internet yang cukup mahal agar dapat mengikuti kelas TIM dengan fitur meeting, mahasiswa merasa itu adalah hal yang tepat sama halnya saat bersekolah secara normal. [11]

Pemanfaatan aplikasi TEAMS peserta didik dapat belajar dengan baik, membuka peluang dalam mempermudah belajar serta peserta didik senang dikarenakan dapat bertemu dengan pendidik serta memperoleh uraian tugas serta materi dari pendidik walaupun melalui virtual. Intinya, peserta didik menganggap aplikasi TEAMS dapat memberi kesenangan serta kesempatan melanjutkan pembelajaran dari rumah dengan mudah selama kegiatan belajar mengajar Jarak Jauh. Peserta didik serta pendidik masih bisa melakukan kegiatan pembelajaran secara efektif serta mengadaptasi kegiatan belajar mengajar saat pandemi secara menyenangkan walaupun harus belajar memanfaatkan aplikasi teknologi yang memerlukan internet serta ponsel pintar maupun komputer. Peserta didik serta pendidik saling mendorong dalam melakukan tahap pembelajaran yang berkesinambungan.[11]

Adaptasi di masa pandemi menuntut seluruh elemen pendidikan untuk beradaptasi dan terus belajar agar efektif dan efisien. Adaptasi dilakukan untuk siswa sekolah dasar di satu tempat, yaitu dengan layanan bimbingan belajar. Peserta merasa senang bisa belajar bersama lagi secara langsung, lebih memahami materi selama hands-on learning, antusias menyelesaikan pekerjaan rumah, belajar percaya diri, belajar berbicara di depan umum, belajar bahasa Inggris. Respon dari orang tua sangat baik. Orang tua siswa mengatakan bahwa layanan bimbingan belajar sangat membantu anak-anak untuk kembali bersekolah. Adanya kegiatan belajar mengajar online juga menuntut kreativitas pendidik agar menggunakan media pembelajaran alternatif selama siswa belajar dari rumah dengan tujuan menimbulkan minat serta semangat siswa selama mengikuti kegiatan belajar mengajar. Media jaringan belajar jarak jauh dengan menerapkan metode pemberian tugas online pada peserta didik dengan group WhatsApp dipandang efektif dalam situasi saat ini. Sebagian besar pendidik menerapkan dalam berbagai teknik pembelajaran dari rumah, yang berbasis online. Ada yang menerapkan konsep kuliah daring, ada yang masih mengajar di kelas seperti biasa namun direkam lalu dishare ke aplikasi WhatsApp siswa, ada pula yang menggunakan konten free melalui beragam sumber. Pembelajaran dari rumah bukan merupakan permasalahan dikarenakan belajar dapat dilaksanakan tidak terbatas ruang dan waktu berbasis online. Sehingga tahap belajar dapat berlangsung dari rumah, di sekolah atau di masyarakat. Fasilitas internet mendukung terlaksananya pembelajaran dengan baik.[12]

Kesiapan institusi pendidikan untuk melaksanakan pembelajaran online menjadi permasalahan tersendiri, hal ini dikarenakan pembelajaran online pada masa pandemi dilakukan secara mendadak, baik institusi pendidikan tersebut siap atau tidak. Tersedianya perangkat teknologi yang ada pada lembaga pendidikan dapat mendukung kegiatan belajar mengajar, kompetensi guru serta staff dalam memanfaatkan teknologi, kompetensi siswa dalam memanfaatkan teknologi, terbatasnya perangkat teknologi yang siswa miliki, akses internet yang tidak stabil di rumahnya, dan hambatan biaya akibat metode pembelajaran yang dilakukan secara online tentunya akan mempengaruhi kualitas pembelajaran secara online. Dengan adanya pandemi yang menuntut institusi pendidikan agar meninggalkan kegiatan belajar mengajar konvensional tatap muka dan menggantinya dengan metode pembelajaran online penuh, ada ruang untuk mengkaji apakah metode pembelajaran online yang diterapkan lebih efektif jika dibandingkan dengan pembelajaran tatap muka.[1]

Berdasarkan hasil penelitian dapat disimpulkan yakni di saat darurat selama pandemi, dimana kegiatan belajar mengajar online merupakan satu-satunya alternatif yang dapat digunakan oleh perguruan tinggi dalam menjamin kegiatan belajar mengajar tetap berjalan, dianggap dapat menjadi pilihan 
pengganti kegiatan belajar mengajar tatap muka konvensional. Namun adanya penerapan kegiatan belajar mengajar online yang dilaksanakan tiba-tiba serta tidak adanya persiapan, tujuan kegiatan belajar mengajar belum tercapai. Tersedianya fasilitas teknologi informasi yang menunjang kegiatan belajar mengajar online, kompetensi mahasiswa serta dosen dalam memanfaatkan teknologi dalam menunjang kegiatan bealajar mengajar, serta kondisi jaringan internet yang stabil sangat mempengaruhi kesuksesan kegiatan belajar mengajar online dalam rangka mencapai tujuan belajar mengajar. Agar kegiatan belajar mengajar online semakin efektif maka diperlukan persiapan fasilitas teknologi informasi yang mampu menunjang kegiatan belajar mengajar online oleh perguruan tinggi maupun oleh pemerintah, mahasiswa dan dosen juga diberikan pelatihan menggunakan fasilitas teknologi informasi tersebut untuk mempermudah bagi dosen dan mahasiswa untuk berinteraksi dengan pembelajaran menggunakan teknologi informasi. Selain itu, subsidi paket data bagi siswa kurang mampu dapat menjadi solusi dari mahalnya biaya pembelajaran online.[1]

Pendidik merupakan garda pendidikan paling depan, mengemban tugas pengajaran, mendidik, memberikan arahan serta bimbingan, melatih, menilai hingga mengevaluasi sampai mendukung moral serta mental pada siswa. Tahap pembelajaran yang dilakukan pendidik serta siswa umumnya dilaksanakan di sekolah (interaksi langsung) tidak melalui media perantara. Namun, akhir-akhir ini tugas pendidik menjadi berubah saat kegiatan pembelajaran dikarenakan adanya virus.[2]

\section{Beberapa faktor pendukung} pembelajaran online antara lain handphone, kuota serta jaringan internet yang stabil. Faktor ini digunakan secara optimal oleh pendidik saat memantau perkembangan siswa dalam melaksanakan pembelajaran online. Orang tua memiliki peran penting terlaksananya kegiatan belajar mengajar online, dikarenakan orang tua terlibat langsung saat pembimbingan serta pengawasan siswa saat kegiatan belajar mengajar. Motivasi yang diberikan menjadi sangat bermakna terhadap siswa, hal ini dilaksanakan supaya siswa semangat lagi walaupun sedang belajar di rumah.[2]

\section{Cara Mengatasi Hambatan Belajar Online}

Belum meredanya wabah virus corona membuat Pemerintah menambah masa pembelajaran di rumah sampai waktu yang belum ditentukan. Beberapa wilayah pedesaan yang belum memiliki jangkauan listrik serta belum ratanya penggunaan media elektronik. Tanpa gadget serta listrik, pendidik di wilayah tersebut ekstra kerja keras. Pendidik harus mendatangi peseta didik satu per satu, untuk menyampaikan pelajaran tatap muka di rumah peserta didik. Kegiatan pembelajaran di rumah dilaksanakan dengan jaga jarak, menggunakan masker, serta selalu cuci tangan. Di wilayah pedesaan ditemui keseluruhan peserta didik tidak memiliki ponsel android dan laptop. Sehingga materi online sedikit terkendala saat diterapkan serta dirasakan keseluruhan sekolah hampir sama. Cara mengatasi sulitnya listrik serta tidak adanya gadget, pembelajaran manual di rumah masing-masing peserta didik diterapkan pendidik.[5]

\section{Dampak Selama Pandemi}

Pandemi telah memberi dampak cukup signifikan pada beragam sektor, salah satunya pendidikan, sehingga menuntut penyelenggaraan pendidikan dilaksanakan jarak jauh. Bahkan sebagian besar sekolah yang mengalami kesulitan saat menyelenggarakan serta melakukan kegiatan belajar mengajar yang mutakhir dengan penggunaan teknologi informasi. Hasil penelitian menunjukkan adaptasi salah satu sekolah yaitu menerapkan perubahan manajemen pendidikan melalui sistem pembelajaran jarak jauh, mengoptimalkan peran kepala sekolah, asisten kurikulum serta pendidik, berinteraksi terus menerus dengan wali murid serta optimalisasi pemanfaatan aplikasi WhatsApp sebagai media komunikasi selama belajar.[4]

Kegiatan belajar mengajar tetap berjalan harus dipastikan oleh guru, walaupun siswa berada di rumah. Guru dituntut merancang media belajar mengajar sebagai suatu inovasi dengan menggunakan media online. Sehingga siswa dipastikanoleh guru agar ikut dalam kegiatan belajar mengajar di saat bersamaan walaupun pada tempat yang tidak sama. Pendidik dapat memberikan penugasan yang terukur disesuaikan tujuan materi yang diberikan pada siswa. Namun permasalahan yang sering 
dialami saat menerapkan sistem kegiatan belajar mengajar online antara lain ketimpangan peserta didik serta orang tua yang pintar mengoperasikan media online, tidak keseluruhan orang tua peserta didik bisa membayar kuota internet, sinyal internet di rumah siswa tidak terjangkau, sebagian besar orang tua peserta didik yang memiliki kondisi ekonomi menengah ke bawah, juga belum mempunyai smartphone sebagai sarana pembelajaran online bagi anaknya.

Permasalahan dalam dunia pendidikan yakni kegiatan belajar mengajar yang beragam, baik standar maupun kualitas hasil belajar yang diinginkan. Dampak yang ditimbulkan yakni tekanan fisik dan psikis. Pola pikir positif bisa mendukung penerapan media pembelajaran online, hingga memberikan hasil belajar dengan kualitas baik. Pembelajaran dari rumah memanfaatkan media online dengan berharap pada orang tua menjadi panutan dalam mendampingi belajar anaknya. Masa pandemi ini dapat disebut sebagai kesempatan dalam dunia pendidikan, baik dalam penggunaan teknologi sejalan dengan Industri 4.0, maupun orang tua sebagai pembimbing.[5]

Salah satu dampak pandemi adalah transformasi media belajar mengajar sebelumnya lebih banyak menggunakan sistem tatap muka di kelas. Ada beragam media belajar mengajar online yang dapat dipilih saat adaptasi pembelajaran saat pandemi, antara lain: a. grup WhatsApp. b. google suite for education. c. ruangguru. d. Zenius. e. Zoom.[5]

\section{Langkah-Langkah Pemecahan Masalah Pembelajaran Online Selama Pandemi}

Solusi kegiatan belajar mengajar di saat pandemi yakni penerapan kegiatan belajar mengajar online, hingga bisa menurunkan tingkat menyebarnya virus. Kegiatan belajar mengajar online memberikan kebebasan pada peserta didik dalam memperoleh informasi dengan leluasa melalui beragam sumber, sehingga membuat peserta didik semakin leluasa mengkonstruksi pengetahuan sehingga dapat membentuk pemahaman pribadi. Tentu saja hal ini hanya dapat terjadi jika proses belajar mengajar berlangsung aktif, kondusif, serta efektif. Dibutuhkan upaya yang komprehensif antara pendidik dan peserta didik. Pendidik harus mampu menciptakan kegiatan belajar mengajar online yang berkualitas serta peserta didik harus dapat mengikuti kegiatan belajar mengajar dengan baik. Meminimalisir faktor penghambat mulai dari akses internet, kendala waktu serta mutu kegiatan belajar mengajar harus segera diatasi agar kegiatan belajar mengajar online bisa dilaksanakan dengan positif.[3]

Solusinya antara lain mengadakan seminar, workshop, penataran dan pelatihan bagi pendidik terkait pemanfaatan teknologi informasi dalam pembelajaran, pembinaan dan pendampingan bersama antara pendidik dan orang tua. Sekolah mencukupi keperluan tenaga pendidik saat penyelenggaraan kegiatan belajar mengajar berbasis internet, menyepakati bersama dari sekolah agar memperoleh jaringan serta kuota internet yang dapat membantu kegiatan belajar mengajar serta memanfaatkan aplikasi yang semakin variatif dalam melaksanakan kegiatan belajar mengajar jarak jauh.[4]

Pilihan yang dianjurkan adalah memeriksa kesiapan serta memilih peralatan paling relevan dengan menentukan pemanfaatan solusi teknologi tinggi serta rendah sesuai dengan keandalan pasokan listrik lokal, konektivitas internet, serta keterampilan digital pendidik serta peserta didik. Memastikan dimasukkannya program pembelajaran jarak jauh, penerapan tahap-tahap yang menjamin peserta didik termasuk yang memiliki kebutuhan khusus maupun dengan latar belakang penghasilan rendah mempunyai akses ke program pembelajaran jarak jauh, mereka pun harus mempunyai akses ke perangkat digital. [3]

\section{Kesimpulan}

Kesimpulan pada penelitian ini menunjukkan adaptasi pendidikan berbasis teknologi dalam menghadapi pandemi Covid-19 dalam berbagai bentuk antara lain a) kesiapan SDM: Pendidik memberikan materi melalui media online google classroom, google meet, zoom, google form, youtube, peserta didik menerima materi menggunakan media sejenis yang diberikan Pendidik. b). Kesiapan materi pembelajaran: materi dikemas secara menarik, mudah dipahami dalam berbagai bentuk seperti power point, video pembelajaran/praktikum. c). Kesiapan model pembelajaran relevan yakni model pembelajaran berbasis student centered, pembelajaran berpusat pada siswa dengan materi yang dikemas Guru berbentuk video, siswa mengembangkannya menggunakan berbagai sumber, kemudian mengkaitkannya antara permasalahan dan teori. d). Kesiapan fasilitas 
pembelajaran berbasis IT: pendidik, peserta didik, pihak sekolah, lingkungan belajar memerlukan perangkat pembelajaran berbasis online dengan jaringan internet stabil, leptop , hand phone, kuota internet. Kendala utama pada proses adaptasi pendidikan berbasis teknologi yakni kesiapan sarana dan prasarana berupa terbatasnya perangkat leptop, hand phone, kuota internet. Hal ini membutuhkan kerjasama berbagai pihak yang terlibat dalam dunia pendidikan sebagai adaptasi pendidikan berbasis teknologi dalam menghadapi Pandemi Covid-19.

\section{Ucapan terima kasih}

Penulis mengucapkan terima kasih atas Akademi Maritim Nusantara atas dukungan finansialnya pada kajian ini.

\section{Daftar Pustaka}

[1] A. Damayanthi, "Efektivitas Pembelajaran Daring di Masa Pandemi Covid 19 pada Perguruan Tinggi Keagamaan Katolik," Edutech, vol. 19, no. 3, pp. 189-210, 2020, [Online]. Available:

http://sosial.unmermadiun.ac.id/index.ph $\mathrm{p} / \mathrm{sosial} /$ article/view/61.

[2] H. Putria, L. H. Maula, and D. A. Uswatun, "Analisis Proses Pembelajaran dalam Jaringan (DARING) Masa Pandemi Covid- 19 Pada Guru Sekolah Dasar," J. Basicedu, vol. 4, no. 4, pp. 861-870, 2020, doi: 10.31004/basicedu.v4i4.460.

[3] F. Firdaus, "Implementasi Dan Hambatan Pada Pembelajaran Daring Di Masa Pandemi Covid 19," utile J. Kependidikan, vol. 6, no. 2, pp. 220-225, 2020, doi: 10.37150/jut.v6i2.1009.

[4] Sumarno, "Adaptasi Sekolah Dalam Mengimplementasikan Pembelajaran Jarak Jauh Pada Masa Pandemi Covid-19 (Studi Kasus Smp Muhammadiyah Karanggeneng Kabupaten Lamongan)," $J$. Tarb. Ilmu Kegur. Borneo, vol. I, no. 2, pp. 149-162, 2020.

[5] L. G. M. Z. Atsani, "Transformasi Media Pembelajaran Pada Masa Pandemi Covid19," Al-Hikmah J. Stud. Islam, vol. 1, no. 1, pp. 82-93, 2020, [Online]. Available: http://journal.unj.ac.id/unj/index.php/jtp.

[6] Y. I. Lindawati and C. A. Rahman,
"Adaptasi Guru Dalam Implementasi Pembelajaran Daring Di Era Pandemi Covid-19," Pros. Semin. Nas. Pendidik. FKIP, vol. 3, no. 1, pp. 60-67, 2020, [Online]. Available: http://www.tjyybjb.ac.cn/CN/article/dow nloadArticleFile.do?attachType=PDF\&id $=9987$.

[7] N. B. Argaheni, "Sistematik Review: Dampak Perkuliahan Daring Saat Pandemi COVID-19 Terhadap Mahasiswa Indonesia," PLACENTUM J. Ilm. Kesehat. dan Apl., vol. 8, no. 2, pp. 99-108, 2020, doi: 10.20961/placentum.v8i2.43008.

[8] S. Nuryatin, "Adaptasi Metode Pembelajaran melalui E-Learning untuk menghadapi Era New Normal," FKIP Univ. Lambung Mangkurat, 2020.

[9] L. D. Herliandry, N. Nurhasanah, M. E. Suban, and H. Kuswanto, "Pembelajaran Pada Masa Pandemi Covid-19," JTP - J. Teknol. Pendidik., vol. 22, no. 1, pp. 6570, 2020, doi: 10.21009/jtp.v22i1.15286.

[10] F. Munirah, "Analisis Isi Deskriptif Rubrik 'Xp Re Si ' Harian Kaltim Post Periode Maret-April 2013," eJournal Ilmu Komun., vol. 3, no. 1, pp. 186-197, 2015.

[11] Y. Kartini, "Penggunaan Aplikasi Teams dalam Pembelajaran Jarak Jauh Di SMAN 18 Surabaya," J. Pendidik. Indones., vol. 2, no. 2, pp. 328-341, 2021, [Online].

Available: https://scholar.google.co.id/citations?user =3APHLTMAAAAJ\&hl=id\#d=gs_md_ci ta-

$\mathrm{d} \& \mathrm{p}=\& \mathrm{u}=\% 2$ Fcitations $\% 3$ Fview_op\%3D view_citation\%26hl\%3Did\%26user\%3D 3APHLTMAAAAJ\%26citation_for_view \%3D3APHLTMAAAAJ\%3Au5HHmVD _uO8C\%26tzom\%3D-420.

[12] J. T. B. Santoso, P. Cahyani, Khusna, Sulistyawati, and F. M. I. Nur, "Pendampingan Belajar dari Rumah Siswa Sekolah Dasar di Masa Pandemi Covid-19 di Kecamatan Pegandon Kabupaten Kendal." 